
\title{
$\begin{array}{ll}\text { Research Square } & \begin{array}{l}\text { Preprints are preliminary reports that have not undergone peer review. } \\ \text { They should not be considered conclusive, used to inform clinical practice, } \\ \text { or referenced by the media as validated information. }\end{array}\end{array}$
}

\section{High-throughput cloning and expression in Lactococcus lactis}

\section{Eric R. Geertsma}

University of Groningen, Biochemistry department

\section{Bert Poolman}

University of Groningen, Biochemistry department

\section{Method Article}

Keywords: high-throughput cloning and expression, ligation-independent cloning, vector backbone exchange (VBEx), Lactococcus lactis

Posted Date: July 25th, 2007

DOI: https://doi.org/10.1038/nprot.2007.290

License: (c) (1) This work is licensed under a Creative Commons Attribution 4.0 International License. Read Full License 


\section{Abstract}

\section{Introduction}

We have developed a generic method for high-throughput cloning in bacteria less amenable to conventional DNA manipulations. The method employs ligation-independent cloning in an intermediary _Escherichia coli_vector, which is rapidly converted via vector backbone exchange $($ VBEx) into a bona fide, organism-specific plasmid ready for high-efficiency transformation. Here, we describe the VBEX procedure for_Lactococcus lactis_. The procedure will yield_L. lactis_ expression vectors from which the gene of interest can be expressed with a cleavable decaHis-tag or alternative tags at either the $\mathrm{N}$ - or Cterminus. Simultaneously, _E. coli_expression vectors holding similar tags can be created.

\section{Reagents}

Plasmid isolation kit \(e.g., Wizard® Plus SV Minipreps DNA Purification System, Promega) T10E0.2 \(10 mM Tris, 0.2 mM EDTA, pH 7.5) Na-acetate, 3 M, pH 5.3 MilliQ Ethanol, 96\%, ice-cold Ethanol, $70 \%$, icecold Phenol:chloroform \(50/50 v/v) Chloroform Tubes $\backslash(1.5 \mathrm{ml}$, PCR tubes) DpnI (Roche) Swal + 10x Swal restriction buffer $\backslash$ (Roche), or its isoschizomer Smil + restriction buffer $\backslash$ (Fermentas). Note: digestion with Smil is done at $30^{\circ} \mathrm{C}$ and not at $25^{\circ} \mathrm{C}$. Sfil $+10 x$ Sfil restriction buffer $\backslash($ Fermentas) Phusion DNA polymerase $+5 x$ Phusion HF buffer and $5 x$ Phusion GC buffer $\backslash$ (Finnzymes) dNTP solution $\backslash(10 \mathrm{mM}$ each; Roche) Primers $\backslash$ (desalted, HPLC purification is not necessarily) TAE, $1 \times$ buffer: $980 \mathrm{ml}$ milliQ +20 ml 50X TAE buffer TAE, 50x buffer: $242 \mathrm{gr}$ Tris-base, $57.1 \mathrm{ml}$ acetic acid, $100 \mathrm{ml} 0.5 \mathrm{M}$ EDTA, pH 8, add water to $1000 \mathrm{ml}$ Agarose Gel purification kit $\backslash$ (e.g., GFX PCR DNA \& Gel Band Purification Kit, GE) dCTP, 25 mM dGTP, 25 mM T4 DNA polymerase + 5x T4 DNA polymerase buffer \(Roche) T4 DNA ligase + 10x T4 DNA ligase buffer $\backslash($ Roche) Na2-ATP, $150 \mathrm{mM}$, pH 7 $\backslash$ (set pH with $\mathrm{NaOH}$ ) E. coli MC1061, calciumcompetent L. lactis NZ9000, electrocompetent $\backslash$ (see protocol below) Luria Broth $\backslash(\mathrm{LB})$, LB agar $\backslash(1.5 \%)$ M17, M17 agar $\backslash(1.5 \%) \backslash($ Difco) Glucose, $20 \% \backslash(\mathrm{w} / \mathrm{v})$ Sucrose, $2 \mathrm{M}$ Ampicillin, $100 \mathrm{mg} / \mathrm{ml}$ in milliQ Chloramphenicol, $5 \mathrm{mg} / \mathrm{ml}$ in EtOH pRExLIC vectors or derivatives $\backslash($ see Table 1) pERL plasmid

\section{Equipment}

Table centrifuge Small-volume spectrophotometer \(Nanodrop, NanoDrop Technologies) Freezer $\backslash\left(-80^{\circ} \mathrm{C}\right)$

\section{Procedure}

**Step $1^{\star \star}$. Purify the pRExLIC vector from an E. coli culture using a plasmid isolation kit. Take $20 \mu \mathrm{g}$ plasmid or more and adjust the volume to $300 \mu \mathrm{l}$ with milliQ. Add $300 \mu \mathrm{l}$ phenol:chloroform and vortex the sample until an emulsion forms. Wait for $2 \mathrm{~min}$ and vortex again. Centrifuge the tube for $2 \mathrm{~min}$ at $16,100 \mathrm{~g}$ and transfer the upper aqueous phase to a fresh tube without disturbing the interface. Add an equal volume of chloroform to the aqueous phase, vortex and centrifuge for $2 \mathrm{~min}$ at $16,100 \mathrm{~g}$. Transfer the upper aqueous phase to a fresh tube. Add 0.1 volume $3 \mathrm{M} \mathrm{Na}$-acetate, $\mathrm{pH} 5.3$, and 2.5 volumes ice- 
cold $96 \%$ ethanol and then vortex the sample. Store the sample at $-80^{\circ} \mathrm{C}$ for $30 \mathrm{~min}$ in a cooling block or use dry ice. Centrifuge for $15 \mathrm{~min}$ at $16,100 \mathrm{~g}$ at $4^{\circ} \mathrm{C}$. Remove the supernatant without disturbing the pellet and slowly add $1 \mathrm{ml}$ ice-cold $70 \%$ ethanol. Centrifuge for $5 \mathrm{~min}$ at $16,100 \mathrm{~g}$ at room temperature. Remove the supernatant without disturbing the pellet and speedvac for $5 \mathrm{~min}$ to remove the last traces of ethanol. Take care not to dry the DNA too long \( 5 min maximally). Dissolve the DNA pellet in $30 \mu$ T10E0.2 by extensively rinsing the walls of the tube with buffer. Determine the DNA concentration and purity using a spectrophotometer. A 260/280 ratio close to 1.8 indicates a pure DNA sample. The purified plasmid can be stored at $4^{\circ} \mathrm{C}$. The $\mathrm{pERL}$ plasmid is isolated from a L. lactis culture using similar procedures as described above, with the following modification: Preceding the cell lysis, cells are resuspended in $10 \mathrm{mM}$ Tris- $\mathrm{HCl}, \mathrm{pH} 8.1,20 \% \backslash(\mathrm{w} / \mathrm{v})$ sucrose, $10 \mathrm{mM}$ EDTA, $50 \mathrm{mM} \mathrm{NaCl}$ plus $10 \mathrm{mg} / \mathrm{ml}$ lysozyme and incubated for $15 \mathrm{~min}$ at $50^{\circ} \mathrm{C}$. ${ }^{\star \star}$ Step $2{ }^{\star *}$. Set up a digestion with $5 \mu \mathrm{g}$ of the purified pRExLIC vector, $2.5 \mu \mathrm{l} \backslash(25 \mathrm{U})$ Swal, $5 \mu \mathrm{l} 10 \mathrm{x}$ Swal-buffer and adjust the volume to $50 \mu \mathrm{l}$. Incubate overnight at $25^{\circ} \mathrm{C}$ in an incubator. Next, analyse the full sample on a TAE-gel using a comb with wide wells $\backslash(\sim 10 \mathrm{~mm})$. Recover the linearized vector using a gel purification kit, elute in $50 \mu \mathrm{l}$ T10E0.2. Remove residual agarose and column material by centrifugation for $5 \mathrm{~min}$ at $16,100 \mathrm{~g}$ and transfer the supernatant to a fresh cup. Determine the DNA concentration and purity using a spectrophotometer. A $260 / 280$ ratio close to 1.8 indicates a pure DNA sample. The Swal-digested vector is stored at $4^{\circ} \mathrm{C}$. ${ }^{*}$ Step $3^{* *}$. Take $200 \mathrm{ng}$ of Swal-digested vector and adjust the volume to $10 \mu \mathrm{l}$ with milliQ. Add $1.5 \mu \mathrm{l} 25 \mathrm{mM} \mathrm{dCTP}$ and $3 \mu \mathrm{l} 5 \mathrm{x}$ T4 DNA polymerase buffer. Add $0.5 \mu \mathrm{I} \backslash(0.5 \mathrm{U}) \mathrm{T} 4 \mathrm{DNA}$ polymerase, vortex shortly and incubate the sample at $20^{\circ} \mathrm{C}$ for $30 \mathrm{~min}$. Heat inactivate the T4 DNA polymerase by incubating at $75^{\circ} \mathrm{C}$ for $20 \mathrm{~min}$. The material can be stored at $4^{\circ} \mathrm{C}$ for several months. ${ }^{*}$ Step $4^{\star \star}$. Design gene-specific primers extended at the $5^{\prime}$ side with LIC-specifiC extensions tails $\backslash$ (see Table 2). Do not include the start and stop codons in the gene-specific part of the primer, these are already present in the LIC specific tails. The annealing temperature of the gene-specific part should be sufficiently high $\backslash$ (preferably above $55^{\circ} \mathrm{C}$ ) to allow specific amplification by PCR. Furthermore, the primer should be without hairpin loops that could interfere with the PCR. No modifications to the LIC-specific extensions should be made. Total primer length should be kept below 50 residues to decrease synthesis-costs and assure a sufficient quality. ${ }^{\star *}$ Step $5^{\star \star}$. Amplify the gene of interest from genomic or plasmid DNA using Phusion DNA polymerase $\backslash$ (Finnzymes). Set up a $25 \mu \mathrm{l}$ reaction with $200 \mu \mathrm{M}$ of each dNTP, $0.5 \mu \mathrm{M}$ of each primer, $5 \mu \mathrm{l} 5 \mathrm{x}$ Phusion HF buffer, template DNA \(0.1$10 \mathrm{ng}$ for plasmid DNA, 25-250 ng for genomic DNA), $0.25 \mu \mathrm{l} \backslash(0.5 \mathrm{U})$ Phusion DNA polymerase. Pre-heat the block of the PCR machine to $98^{\circ} \mathrm{C}$ before adding the Phusion DNA polymerase to the mixture and placing the cup in the PCR machine. Cycle as follows: $30 \mathrm{sec}$ at $98^{\circ} \mathrm{C} ; 15 \mathrm{cycles}$ of $10 \mathrm{sec}$ at $98^{\circ} \mathrm{C}, 20 \mathrm{sec}$ at $60^{\circ} \mathrm{C}, 15$ or $30 \mathrm{sec}$ per kb for plasmid or genomic DNA, respectively. Decrease the annealing temperature every cycle by $0.5^{\circ} \mathrm{C}$. Next, perform 15 cycles of $10 \mathrm{sec}$ at $98^{\circ} \mathrm{C}, 20 \mathrm{sec}$ at $52.5^{\circ} \mathrm{C}, 15$ or $30 \mathrm{sec}$ per kb for plasmid or genomic DNA, respectively; end with a final extension of $5 \mathrm{~min}$ at $72^{\circ} \mathrm{C}$ and hold the sample at $4^{\circ} \mathrm{C}$. If plasmid DNA isolated from dam+ hosts is used as template, it is recommended to add $0.5 \mu \mathrm{I} \backslash(5 \mathrm{U}) \mathrm{Dpnl}$ to the sample and incubate $30 \mathrm{~min}$ at $37^{\circ} \mathrm{C}$. Dpnl will digest Dam-methylated template and thereby reduce the number of background-colonies after transformation. Note: not all hosts perform Dam-methylation. ${ }^{*}$ Step $6 * *$. Analyse the full sample on a TAE-gel and recover the PCR-product using a gel purification kit, elute the DNA in $30 \mu \mathrm{IT10E0.2.} \mathrm{Remove} \mathrm{residual} \mathrm{agarose} \mathrm{and} \mathrm{column} \mathrm{material} \mathrm{by}$ 
centrifugation for 5 min at 16,100g and transfer the supernatant to a fresh cup. Determine the concentration and purity using a spectrophotometer. The sample is stored at $4^{\circ} \mathrm{C}$. ${ }^{\star \star}$ Step $7^{\star \star}$. Take the molar equivalent to $200 \mathrm{ng}$ vector of insert. The amount of insert to be used can be calculated as follows: $\mathrm{ng}$ insert $=\backslash(200 \mathrm{ng}$ * insert size in bp $) /$ vector size in bp. Adjust the volume to $10 \mu \mathrm{l}$ with milliQ. Add 1.5 $\mu \mathrm{l} 25 \mathrm{mM}$ dGTP and $3 \mu \mathrm{l} 5 \mathrm{x}$ T4 buffer. Add $0.5 \mu \mathrm{l} \backslash(0.5 \mathrm{U})$ T4 DNA polymerase, vortex shortly and incubate the sample at $20^{\circ} \mathrm{C}$ for $30 \mathrm{~min}$. Heat inactivate the T4 DNA polymerase by incubating at $75^{\circ} \mathrm{C}$ for $20 \mathrm{~min}$. The material can be stored at $4^{\circ} \mathrm{C}$ for several months. ${ }^{*}$ Step $8^{* \star}$. Add $1 \mu$ l of vector $\backslash(\operatorname{step} 3)$ to $3 \mu \mathrm{l}$ of insert \(step 7) and incubate for $5 \mathrm{~min}$ at room temperature. Transform the material to $75 \mu \mathrm{l}$ chemically competent_E. coli_ MC1061 according to standard protocols. Plate 0.1 and 0.9 volume of transformed cells on LB agar supplemented with $100 \mu \mathrm{g} / \mathrm{ml}$ ampicillin and incubate overnight at $37^{\circ} \mathrm{C}$. Analyse the colonies by colony PCR and isolate plasmid using a plasmid isolation kit. No additional purification of the plasmid is needed. Sequence the insert. Note: inserts amplified with primers with nLIC-extensions $\backslash$ (Table 1) are compatible with all plasmids holding an nLIC-cassette $\backslash($ Table 2). For example, using one nLIC-insert, both plasmids pREnLIC-insert and pBADnLIC-insert can be created. The pBAD-derived vectors can immediately be used for expression analysis in E. coli using the AraC/PBAD expression-system \ (Guzman_et al_, 1995) and should not be submitted to step 9. Similar, all inserts amplified with primers with cLIC-extensions $\backslash($ Table 1$)$ are compatible with all plasmids holding a cLIC-cassette $\backslash$ (that are: pREcLIC, pREcLIC-GFP, pBADcLIC, pBADcLIC-GFP; Table 2). The preparation of pBADxLIC vectors is identical to the preparation of the pRExLIC vectors described in step 1-3. **Step 9**. Mix approximately $125 \mathrm{ng}$ of the pERL plasmid \(isolated in step 1) and approximately $125 \mathrm{ng}$ of a pRExLIC-derived vector containing the insert \(isolated in step 8). Adjust the volume to $10 \mu \mathrm{l}$ by adding $1 \mu \mathrm{l} 10 \mathrm{x}$ Sfil-buffer, $0.5 \mu \mathrm{l} \backslash$ (5U) Sfil \(Fermentas) and sufficient milliQ. Use a PCR machine with heated lid to incubate the sample for $80 \mathrm{~min}$ at $50^{\circ} \mathrm{C}$ and $20 \mathrm{~min}$ at $80^{\circ} \mathrm{C}$ to inactivate Sfil. After cooling to room temperature, start the ligation by the addition of $1.5 \mu \mathrm{l} 8 \mathrm{mM} \mathrm{Na2-ATP,} \mathrm{pH} \mathrm{7,} \mathrm{and} 0.5 \mu \mathrm{I}(0.5 \mathrm{U})$ T4 DNA ligase. Incubate the sample for 1 hr at $20^{\circ} \mathrm{C}$ and, subsequently, $20 \mathrm{~min}$ at $65^{\circ} \mathrm{C}$ to heat inactivate the T4 DNA ligase. Transform $2 \mu \mathrm{l}$ of sample to $30 \mu$ lelectrocompetent L. lactis NZ9000 \(see protocol below) and plate aliquots on M17 plates supplemented with $0.5 \% \backslash(\mathrm{w} / \mathrm{v})$ glucose, $0.5 \mathrm{M}$ sucrose and $5 \mu \mathrm{g} / \mathrm{ml}$ chloramphenicol. Seal the plates with parafilm and incubate at $30^{\circ} \mathrm{C}$ until colonies appear $\backslash(\sim 18 \mathrm{hrs})$. The pNZxLIC vectors derived in this step can immediately be used for expression analysis in L. lactis using the nisin-controlled expression-system \(for details, see Kunji_et al_, 2003 and de Ruyter_et al_, 1996) **Electrotransformation of L. lactis**. Preparation of electrocompetent L. lactis NZ9000 was essentially done as described $\backslash$ (Holo and Nes, 1989; Wells_et al_, 1993), but with some critical modifications. Briefly: Streak a frozen stock of L. lactis NZ9000 on M17 agar supplemented with $0.5 \% \backslash(\mathrm{w} / \mathrm{v})$ glucose and incubate overnight at $30^{\circ} \mathrm{C}$. Use a single colony to inoculate $5 \mathrm{ml} \mathrm{M} 17$ supplemented with $0.5 \% \backslash(\mathrm{w} / \mathrm{v})$ glucose. Grow at $30^{\circ} \mathrm{C}$ for 6 h. Use this culture to inoculate $50 \mathrm{ml} \mathrm{M17}$ supplemented with $0.5 \% \backslash(\mathrm{w} / \mathrm{v})$ glucose plus $1 \% \backslash(\mathrm{w} / \mathrm{v})$ glycine and incubate overnight. Note: glycine can be autoclaved with the medium, sucrose and glucose need to be added seperately. Use the $50 \mathrm{ml}$ culture to inoculate $400 \mathrm{ml} \mathrm{M17} \mathrm{supplemented} \mathrm{with} 0.5 \% \backslash(\mathrm{w} / \mathrm{v})$ glucose, $0.5 \mathrm{M}$ sucrose and $2 \% \backslash(\mathrm{w} / \mathrm{v})$ glycine and continue cultivation until $\mathrm{OD} 600=0.5$. Harvest the cells by centrifugation at $5000 \mathrm{~g}$ for $15 \mathrm{~min}$ at $4^{\circ} \mathrm{C}$. Wash the cells with 1 volume ice-cold solution $\mathrm{A} \backslash(0.5 \mathrm{M}$ sucrose and $10 \% \backslash(\mathrm{v} / \mathrm{v})$ glycerol, prepared in milliQ) and centrifuge at $5000 \mathrm{~g}$ for $15 \mathrm{~min}$ at $4^{\circ} \mathrm{C}$. Next, resuspend the cells in 0.5 volume ice-cold solution A supplemented with 
$50 \mathrm{mM} \mathrm{Na}-E D T A, \mathrm{pH} 7.5$, and 0.25 volume solution $\mathrm{A}$, and incubate for $15 \mathrm{~min}$ on ice before centrifugation at $5000 \mathrm{~g}$ for $15 \mathrm{~min}$ at $4^{\circ} \mathrm{C}$. Finally, resuspend the cells in 0.01 volume ice-cold solution $\mathrm{A}$. Aliquots of $40 \mu \mathrm{l}$ are flash-frozen in liquid nitrogen and stored at $-80^{\circ} \mathrm{C}$ until use. For electroporation, thaw cells on ice, combine them with the plasmid DNA, and transfer the sample to an ice-cooled electroporation cuvet $\backslash(2 \mathrm{~mm}$ electrode gap). Expose cells to a single electrical pulse with a field strength of $2 \mathrm{kV}$, capacitance of $25 \mu \mathrm{F}$ and resistance of $200 \mathrm{Ohm}$. Immediately following discharge, mix the cells with $1 \mathrm{ml}$ ice-cold $\mathrm{M} 17$ supplemented with $0.5 \% \backslash(\mathrm{w} / \mathrm{v})$ glucose, $0.5 \mathrm{M}$ sucrose, $20 \mathrm{mM} \mathrm{MgCl}_{2}$ plus $2 \mathrm{mM}$ $\mathrm{CaCl}_{2}$, and leave them on ice for $10 \mathrm{~min}$. Subsequently, incubate the cells at $30^{\circ} \mathrm{C}$ for $2 \mathrm{hrs}$ and plate aliquots on M17 agar supplemented with $0.5 \% \backslash(\mathrm{w} / \mathrm{v})$ glucose, $0.5 \mathrm{M}$ sucrose and $5 \mu \mathrm{g} / \mathrm{ml}$ chloramphenicol. Seal the plates with parafilm and incubate overnight at $30^{\circ} \mathrm{C}$.

\section{Timing}

The full procedure can be performed in 4 days.

\section{Critical Steps}

**Step $1 * \star$. Although the additional phenol:chloroform purification step might seem over-cautious, we find this step essential for high-efficiency digestion with Swal. ${ }^{*}$ Step $3{ }^{* \star}$. More extensive treatment with T4 DNA polymerase resulting from higher incubation temperatures, prolonged incubation or higher concentrations of T4 DNA polymerase will decrease the efficiency of the procedure dramatically. **Step $7^{\star * *}$. More extensive treatment with T4 DNA polymerase resulting from higher incubation temperatures, prolonged incubation or higher concentrations of T4 DNA polymerase will decrease the efficiency of the procedure dramatically.

\section{Troubleshooting}

**Step 6**. If the PCR was not successful, we refer to the manufacturer's protocol for optimization. For complex DNA \(e.g., genomic DNA or GC-rich DNA), the use of $5 x$ Phusion GC buffer should be considered.

\section{Anticipated Results}

The ligation-independent cloning procedure described should yield transformation efficiencies of approximately $10,000 \mathrm{CFU} / \mu \mathrm{g}$ DNA of which at least $90 \%$ will contain the insert. The VBEx procedure will yield transformation efficiencies of approximately 1,000,000 CFU/ $\mu \mathrm{g} D N A$; all the L. lactis transformants will contain the correct insert.

\section{References}


L. M. Guzman, D. Belin, M. J. Carson_et al_., _J Bacteriol_ **177** \(14), $4121 \backslash(1995)$. H. Holo and I. F.

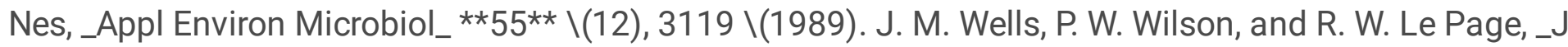
Appl Bacteriol_**74** \(6), $629 \backslash(1993)$ E. R. Kunji, D. J. Slotboom, and B. Poolman, _Biochim Biophys Acta_ ${ }^{\star *} 1610^{\star \star} \backslash(1), 97 \backslash(2003)$ P. G. de Ruyter, O. P. Kuipers, and W. M. de Vos, _Appl Environ Microbiol_ $\star \star 62 * \star \backslash(10), 3662 \backslash(1996)$.

\section{Acknowledgements}

\section{Supplementary Files}

This is a list of supplementary files associated with this preprint. Click to download.

- supplement0.pdf 